über Sicherheit, wirtschaftliche Zusammenarbeit und Entwicklung könnte den Auftakt für einen politischen Prozess darstellen, der zu einem alle Bereiche abdeckenden Grundlagenabkommen, zu Aktionsplänen und anschließenden Überprüfungskonferenzen führt. Kernelemente dieses Vertrags wären ein Gewaltverzicht und die internationale Garantie für eine immerwährende Neutralität Afghanistans.

Gegen diese Option spricht, dass sie von der internationalen Staatengemeinschaft ein radikales Umdenken verlangt, das angesichts der vorherrschenden beschönigenden und realitätsfernen Lageanalyse kaum zu erwarten ist. Dafür dürfte sprechen, dass jede Form der Hybris früher oder später zu Kursänderungen und Strategiewechseln führt.

\section{Schlussfolgerung}

Die dritte Möglichkeit enthält die meisten Handlungsoptionen und bietet auch im Sinne des entwicklungspolitischen
Grundsatzes von „do no harm“ mehr Möglichkeiten, Gewalteskalation zu vermeiden. Wesentliche Gründe dafür sind oben aufgeführt. Die zentralen Faktoren, warum die heutige Strategie des Westens wahrscheinlich scheitern wird, sind kulturelle Differenz, begrenzte Ressourcen und die Unmöglichkeit, das Sozialverhalten einer ganzen Gesellschaft von außen grundlegend zu verändern. Die große Gefahr ist, dass aus Enttäuschung eine doppelte Gegenreaktion hervorgerufen werden könnte. Die afghanische Gesellschaft könnte die internationale Gemeinschaft zunehmend als Besatzer wahrnehmen und die internationale Gebergemeinschaft könnte sich mehr oder weniger abrupt von Afghanistan abwenden. Folglich ist ein umfassender Strategiewechsel notwendig, der fünf Aspekte beherzigt: bescheidenere Ziele, Afghanisierung der Sicherheit, dezentrale Regierungsstrukturen, auf lokale Bedürfnisse ausgerichtete Entwicklung und regionale Einbettung des Afghanistankonflikts.

\title{
NGO Views of NATO Strategy in Afghanistan
}

\author{
Lara Olson and Anja de Beer*
}

\begin{abstract}
NGOs in Afghanistan have long argued that a fundamental flaw of the NATO effort is the extensive involvement of the military in the civilian roles of reconstruction and development. This has undermined humanitarian space and access in Afghanistan, arguably undermining prospects for the overall development effort. NGO advocacy inside Afghanistan and in donor countries has consistently argued for the NATO strategy to address this counterproductive militarization of aid, as well as the need for clear civilian leadership and a unified strategy across all members of the ISAF mission. Furthermore, for the best possible strategies for Afghan recovery to emerge, the views of the NGO sector must be given more than a token role in the policy dialogue with NATO.
\end{abstract}

Keywords: NGOs, Afghanistan, NATO, humanitarian organisations, NROs, Afghanistan, NATO, humanitäre Organisationen

\section{Introduction}

I nternational and Afghan non-governmental organizations (NGOs) constitute a major resource for recovery in Afghanistan given their direct work with Afghan communities, their development expertise, and their major operational role as partners of the Government of Afghanistan (GOA), the United Nations Mission in Afghanistan (UNAMA), and international donors. However, NGOs have faced a very difficult environment in which to make their voices heard. Unlike UN peacekeeping contexts, the international effort in Afghanistan lacks strong civilian leadership and for the last years has been

\footnotetext{
* Lara Olson is Co-Director, Peacebuilding, Development and Security Program, Centre for Military and Strategic Studies, University of Calgary, Canada; Anja de Beer is Director, Agency Coordinating Body for Afghan Relief (ACBAR), Kabul, Afghanistan.
}

led by the US and NATO military mission - by default. Furthermore, 7 years after the fall of the Taliban, Afghanistan is still not a post-conflict country. There continues to be a volatile mixed war and peace context where counterinsurgency strategies, an expansive statebuilding agenda, and reconstruction, relief and development efforts coexist and sometimes collide. Furthermore, the marked deterioration in security in many parts of the country over the past year has given urgency to calls for greater, stronger, tighter coordination of all international efforts.

Today's focus on better coordination and integration within the international effort implies that the fundamental strategies are sound and only the execution is faulty. In contrast, operational humanitarian and development NGOs in Afghanistan have argued continuously for a rethink of some fundamental tenets of the international mission - especially its approach to security and the deep conflation of civilian and military roles in relief, reconstruction and development. 
However, NGO views have had little impact to date. It is fair to say that concerted advocacy by NGO coalitions within Afghanistan and within donor countries has been largely ignored. The engagement of NATO with the NGO sector has more often than not had the flavour of tokenism. Even where goodwill exists, the lack of a unified approach within NATO means engaging in policy dialogue, and advocacy with NATO remains a very difficult proposition for NGOs.

This paper is divided into three parts. Part I reviews the unusual context for aid NGOs in Afghanistan, marked by conflicting frameworks of peacebuilding versus warfighting. Part II describes the roles NGOs have played in Afghanistan over the last 30 years. Part III reviews persistent NGO advocacy on the broader international strategy and calls for a delinking of military and civilian roles, strong civilian leadership under the UN, and real (versus token) participation for NGOs in deliberations over the new integrated approach.

\section{NATO and the International Strategy in Afghanistan}

The complex and unwieldy architecture of the international mission in Afghanistan reflects the distinct agendas of the major actors involved. The two basic paradigms at play in Afghanistan can be summed up as "warfighting" versus "peacebuilding". They reflect a deep tension in the nature of the broader international engagement in Afghanistan, one that creates enormous challenges for NGOs in terms of how they relate to NATO and other architects of the international effort. The juxtaposition of peacebuilding and warfighting goals and interventions has ultimately undermined the space for humanitarian and development NGOs to operate, and ultimately undermined the crucial development agenda of the mission overall.

\subsection{The War Fighting Agenda}

As a result of the expansion of the ISAF mission in Kabul in 2003, NATO took over the command and coordination of ISAF with a two pronged approach: warfighting and counterinsurgency through donor country battle units, and stabilization and reconstruction through the Provincial Reconstruction Teams (PRTs).

The dominant US role in Afghanistan has always been framed in an unapologetic language of war fighting. The US-led invasion and ouster of the Taliban regime as a response to 9/11 was the cornerstone of the war on terror. US policy makers openly talk of the role of development aid as a tool of counterinsurgency, and critics fault the Afghanistan Compact for being incoherent as a "war plan", calling for metrics to measure the things that will matter in "winning the conflict". ${ }^{1}$ Beyond this overt US position, the current military posture of ISAF in Afghanistan's Southern and Eastern provinces is also an explicit warfighting posture. Civil-military doctrine and counterinsur-

\footnotetext{
1 Anthony H. Cordesman, "The Missing Metrics of "Progress" in Afghanistan (and Pakistan). Working Draft presented at the Conference on Peacebuilding in Afghanistan: Taking Stock and Looking Ahead." Ottawa, Canada, December $10-11,2007$.
}

gency doctrine of the US and other troop-contributing countries emphasize the use of aid to civilian populations to ensure force protection, secure intelligence and win the "hearts and minds" of the population - all as explicit elements of a warfighting strategy.

\subsection{The Peacebuilding Agenda}

Peacebuilding, an umbrella term referring to the broad spectrum of efforts for post-conflict recovery in a given crisis, was defined by the Brahimi panel on UN peace operations in 2000 as the creation of conditions for more than just the absence of war. ${ }^{2}$ It includes rebuilding basic infrastructure, reintegrating former combatants, strengthening the rule of law, improving respect for human rights, providing technical assistance for democratic development and promoting economic sustainability, conflict resolution and reconciliation.

In Afghanistan this broad range of efforts is currently funded by donor governments and international financial institutions, and implemented by Afghan government institutions, UN agencies, international and Afghan NGOs, and often, directly by foreign military forces. Donor countries from around the world have met on five occasions to pledge financial aid and set benchmarks. ${ }^{3}$ The latest conference held in Paris in June 2008 endorsed The Afghanistan National Development Strategy as the key framework for cooperation between the Government of Afghanistan, the United Nations, ISAF and the international community.

The NATO-led Provincial Reconstruction Teams (PRTs) are the main framework for international security assistance outside of Kabul: they are provincial bases stood up by "lead nations" and combine small numbers of troops and civilian aid personnel to promote stability and reconstruction in the area. The PRT military contingents are not battle groups, but rather their purpose is to protect the PRT base, to facilitate the movement of civilian development specialists, and to promote stability in the area through their presence. PRTs have been criticized by many for being an unsuccessful attempt at "security on the cheap". ${ }^{4}$ In terms of troop presence and volume of assistance per capita, the mission in Afghanistan is significantly under-resourced compared to other international missions in the 1990s. ${ }^{5}$ To be fair, PRTs are recognized by NATO and donors as a less than ideal solution to security in the provinces, but the only realistic one given constraints on troops available and the "light footprint" strategy decided for the mission early on. In the Southern and Eastern provinces, the co-existence of large battle groups and special forces units doing the war fighting and other soldiers

2 United Nations, Report of the Panel on United Nations Peace Operations (The "Brahimi Report"). A/55/305-S/2000/809, New York, p. 3/

3 The donor conferences include: Bonn in 2001; Tokyo conference in 2002; Berlin in 2004 and London in 2006, and Paris in 2008.

4 Statement of Nancy Lindborg, Executive Vice President, Mercy Corps, Senate Foreign Relations Committee Hearing on: "Afghanistan: In Pursuit of Security and Democracy", October 23, 2003, quoted in Barbara Stapleton, "A Means to What End? Why PRTs are Peripheral to the Bigger Political Challenges in Afghanistan." Journal of Military and Strategic Studies. 10 (1), 2007.

5 Barnet Rubin et al. "Afghanistan 2005 and Beyond: Prospects for Improved Stability Reference Document." Netherlands Institute of International Relations, "Clingendael”, Conflict Research Unit, April 2005, p. 54. 
deployed in the PRTs makes it hard for the local population to differentiate between these different types of soldiers.

These pervasive tensions between the peacebuilding and warfighting mandates are manifested in the deep conflation of military and civilian assistance roles inside Afghanistan. ${ }^{6}$ Since security is seen as the necessary condition for development, and development is seen as the peace dividend that will give Afghans a stake in the new order, these two realms are tightly interlinked in NATO policy. The PRTs are the practical expression of this thinking and are often run as part of the lead nation's "whole of government approach" (WGA) that aims to promote coherence across all relevant civilian and military arms of a donor government. ${ }^{7}$

\section{The Nature of the NGO Sector in Afghanistan}

There are some basic facts behind the perspective the NGO sector brings to the table in Afghanistan that are not widely known. International and Afghan NGos have a long history and deep connections in the country. They have played crucial roles in key sectors such as health, education and rural development. Finally, NGO networks inside Afghanistan and in donor countries have made concerted efforts to influence the international and NATO strategy and have redoubled those efforts recently despite numerous institutional obstacles to engaging in strategic-level advocacy.

The vast majority of NGOs are Afghan NGOs. Of the 1,580 NGOs currently registered with the NGO department of the Ministry of Economy, 1,269 are national and 311 international. They are involved in a wide variety of projects and programmes ranging from health, education, agriculture, shelter, to gender civic education, community level peacebuilding and human rights.

Many of the biggest international and Afghan aid NGOs have been engaged in relief and development support to Afghans for the last 30 years. Even during the Soviet occupation, NGOs like Médecins Sans Frontières, CARE International, World Vision and Oxfam worked from bases in Pakistan running cross-border programs in Afghanistan as well as assisting Afghans in refugee camps. Throughout the 1990s, there was a dramatic growth in the number of national Afghan NGOs whose members received training, support and funding from international NGOs. Under the Taliban regime, some NGOs expanded emergency activities and continued development support despite political restrictions, while others left Afghanistan to protest the regime's human rights policies. ${ }^{8}$

NGOs are not merely subcontractors to donors. As civil society actors, NGOs see their primary loyalty, accountability and responsibility to the people of Afghanistan, and involve Afghans in the conception, implementation and evaluation of

6 Carrie Vandewint, "A Better Helping Hand", Submission to the Manley Panel, Afghanistan Reference Group, December 1, 2007.

7 "Whole of Government Approaches" (or "integrated approaches) is/are the term(s) used by the OECD. Other synonyms include "joined up" government, or "3-Ds"- referring to the key ministries of defense, development and diplomacy.

8 ACBAR, "History of NGOs in Afghanistan." in A Handbook for Understanding NGOs, Kabul 2007, p. 7. the projects and programs. ${ }^{9}$ NGOs place a major priority on capacity building, and the vast majority of staff of international NGOs consists of Afghan nationals.

The Afghan government, international donors and civil society actors all acknowledge that the NGO sector is critical to rebuilding Afghanistan and to providing vital services until the government can effectively assume these roles. NGOs help the government implement key national programs such as the National Solidarity Program (NSP) focused on rural development and the Basic Package Health Services (BPHS). In short, NGOs play a vital role in Afghanistan's recovery. Though hard to pin down, some estimates put the NGO share of service delivery in the health, education and rural development sectors at 70-90 per cent. ${ }^{10}$ Furthermore, NGOs also play an essential role in the vital 'software' side of development - capacity-building and grassroots development.

NGOs have also played an important advocacy role on the international strategy. The diversity of the NGO sector means that in many instances NGOs focus primarily on issues directly relating to their programmes (such as health, education, agriculture). However, many NGOs have come together to undertake joint advocacy on overarching issues like security, civil-military relations and aid effectiveness depending on their mandates. Still, advocacy work requires time and dedicated resources, and it is no surprise that only the very big international NGOs have the resources to hire full-time advocacy staff.

ACBAR is one of four NGO coordinating bodies in Afghanistan, but the one which has pursued the highest-profile advocacy role on behalf of its members. ${ }^{11}$ ACBAR's 100 members include the biggest international and Afghan NGOs. It has been a vocal advocate for issues of humanitarian space with civilian and military actors present in Afghanistan.

NGO coordination networks in some donor countries are also very active. The US NGO coordination body, InterAction, has a longstanding Afghanistan Working Group composed of the major US NGOs working in the country. InterAction's participation in a US civil-military task force resulted in agreed guidelines adopted in July 2007 by the US Department of Defense on relations between US military forces and NGOs. ${ }^{12}$

In Europe, the British and Irish Agencies in Afghanistan Group (BAAG) has tenaciously lobbied the British government on civil-military issues and the PRTs. Similarly, the European Network of Agencies in Afghanistan, based in Brussels as a convening body for NGOs from Germany, Netherlands, France, Sweden and Norway, works closely with BAAG in advocacy on civil-

9 ACBAR (2007)

10 World Bank, "Service Delivery and Governance at the Sub-National Level in Afghanistan," Washington, DC, July 2007, p. 26.

11 Other NGO coordination bodies are the Afghan NGOs Coordination Bureau (ANCB), the Islamic Coordination Council (ICC) and the South West Afghanistan and Baluchistan Association for Coordination (SWABAC). Of these, only ACBAR has a formalized collaboration with UNAMA while the others have established links with the Afghan Transitional Authorities or local authorities.

12 Interaction, U.S. Institute of Peace and Department of Defense, "Guidelines for Relations between U.S. Armed Forces and Non-Governmental Humanitarian Organizations in Hostile or Potentially Hostile Environments." http:// www.interaction.org/files.cgi/5896_InterAction_US_Mil_CivMil_Guidelines_July_07_flat.pdf 
military relations, and released a major research report in June $2008 . .^{13}$

\section{NGO Critiques of NATO Strategy}

\subsection{The Militarization of Aid}

The NGO sector has consistently condemned the deep conflation of military and aid roles that is the basis of the PRT approach. They link this approach to the alarming deterioration in the security of NGO personnel - more than 100 aid workers have been deliberately killed since 2003 by anti-government groups. Rising insecurity has led NGOs to sharply curtail operations and caused major gaps in urgently needed assistance to Afghans.

Much of the debate on NGO insecurity and the resulting reduced humanitarian access has focused on the "blurring of the lines" that has occurred due to the PRTs and the widespread use of aid to win "hearts and minds", gather intelligence, and ensure force protection by foreign combat units. As this has undermined the perceived impartiality of NGOs, it has "reduced the areas in which NGOs can safely undertake development and humanitarian activities." 14 This practice has in essence turned aid workers into legitimate war targets in the eyes of insurgent groups, which was not the case even during the Taliban regime. Furthermore, especially local NGOs fear that if they accept funding for development work from PRTs they will be accused of being partners with the military or "spies". ${ }^{15}$

NGOs can be very wary of openly coordinating with the PRTs and the military, due to the need to preserve principles of impartiality and the independence but also because of the security implications of NGO staff being linked to the PRT. One of the most difficult areas of coordination between NGOs and the PRTs is basic information sharing. It is recognized that PRTs and NGOs are operating in the same space, and either side ignoring the other can do more harm than good for the local people. Yet supplying information to a PRT or the military, even on something as seemingly benign as a shelter programme, could seriously threaten the lives of NGO staff and their ability to operate. In one of many such examples, NGO offices in Nangarhar were visited by groups opposed to the Afghan Government who searched NGO documents and computers for proof of contacts with the military. "Night letters" have been circulated accusing NGOs of spying for the Americans and warning Afghans not to work for international NGOs. NGOs with deep roots in communities have been warned that they can no longer be 'protected' by the village if they work with the foreign military forces.

Though most operational NGOs are pragmatic and forge working relationships with the PRTs, the NGO position remains that

13 Sippi Azarbaijani-Moghaddam and Mirwais Wardak. "Afghan Hearts, Afghan Minds: Exploring Afghan perceptions of civil-military relations." British and Irish Agencies Afghanistan Group, June 2008.

14 Matt Waldman, "Falling Short: Aid Effectiveness in Afghanistan." ACBAR Advocacy Series, March 2008, p. 13.

15 Surendrini Wijeyaratne, Peace and Conflict Policy Analyst, Canadian Council for International Cooperation, interview with author, April 2008. there should not be a development role for PRTs. A March 2008 ACBAR report on aid effectiveness reiterated previous calls for a change of emphasis for PRT activities from development to security, and for adherence to previous UN guidelines and agreements on military roles in aid provision that have largely been ignored in Afghanistan. The report went further in urging that the PRTs be closed down in the secure areas of the country and funding channeled through the government instead. ${ }^{16}$

NGOs also have called for the UN mission to take a stronger role on these issues, but point to a lack of resources and capacity for the development and humanitarian coordinator within UNAMA, and also see this unit's subordination to the political dictates of the UN's role in Afghanistan as problematic.

Many NGOs fault the politicization of aid overall in Afghanistan as the real root problem. The whole Afghan recovery process is led by political concerns rather than the needs of Afghans or principles of effective relief and development practice. Arguably, PRTs have had very limited impact on security and reconstruction to date, while their main contributions have been political - to maintain the momentum of the political transition, keep donors engaged, and "enable the appearance of progress" ${ }^{17}$ Furthermore, political criteria has replaced need in terms of targeting aid programs. For example, aid agencies are pushed by donors to initiate work where their host-nations' PRTs are. Dramatically more government assistance is allocated to the insecure areas of the South and East, and areas of high poppy cultivation. ${ }^{18}$ In the eyes of many NGOs, all of these trends diminish their ability to effect real progress on development.

\subsection{The Integrated Approach in Afghanistan}

In February 2008 NATO, UN and GOA came together in Brunssum, the Netherlands to discuss better coordination. The outcome of the discussions was "the integrated approach to stabilization and development in Afghanistan". In presentations of the integrated approach it is stated that the overall strategy for the stabilization and development remains the Afghanistan Development Strategy (ANDS) and that the purpose of the integrated approach is to bring together the various stakeholders under the ANDS framework.

Once again the co-ordination initiative was heavily militaryled, given the fact that the meeting was held in the NATO HQ in Brunssum, and it was marked by a disappointing failure to include either Afghan or international NGOs. The process prior to the Brunssum meeting illustrated a typical approach to the NGO sector. NGOs were invited to a briefing on the integrated approach in the week prior to the Brunssum meeting where they expressed their concerns about the plans and process. The UN promised to convey those concerns at Brunssum. After NGOs repeatedly expressed their disappointment, both UN and ISAF representatives promised to ensure that an invitation was extended to NGO representatives. It was, however, received

16 Waldman (2008), p. 24.

17 Barbara J. Stapleton (2007), p. 4.

18 Waldman (2008), p. 12. 
only at the last moment so NGOs were ultimately unable to send a representative.

Some question whether a spirit of "tokenism" drives the engagement of the NGO sector by donor states and NATO. NGO leaders report they are often invited to high level consultations, but leave with the feeling this is so that the hosts can 'tick off' civil society involvement. As well, states and international organizations reportedly engage NGO coalitions in unhelpful ways that reflect a lack of understanding of the nature of the NGO sector. For example, often ACBAR is invited into consultations at the last minute, with no expectation that time is needed for internal consultation across the diverse NGO sector to enable the representative to bring some substantive input to the table.

NGOs are also concerned that a closer integration of UNAMA and ISAF (leading to a more politicized UN) could have negative effects on UN agencies' ability to deliver aid and assistance. The fear amongst an important group of NGOs is that this could ultimately jeopardize NGOs relations with the UN. This is because stronger links between the UN and NATO in Afghanistan could lead to NGOs having to be more cautious in their interactions with UN agencies in order to preserve their independence. If the UN's neutrality and reputation becomes affected by too close a relationship with ISAF, this would make collaboration and co-ordination with its key civilian partners more difficult.

While some actors are reportedly unhappy with the UN's efforts to date, and criticize it for lagging in its integration with NATO, clearly the UN is being pulled in both directions. The cry for greater coordination has pulled it towards integration with the NATO mission. At the same time, it is pulled away from integration by its NGO partners who are the key implementing agencies for its relief and development agenda).

\subsection{Civilian Leadership of the International Effort}

NGOs argue for the need to establish the primacy of civilian leadership of the mission overall. In order to ensure the sustainability of international efforts, military forces should co-ordinate their activities with civilian actors to support and feed into broader civilian efforts and not vice versa.

NGOs have long advocated increased civilian leadership over development, humanitarian aid and reconstruction in Afghanistan. Normally this leadership would be provided by the UN and the Government of Afghanistan. Unfortunately, the UN is relatively weak and underresourced in Afghanistan in comparison to ISAF and OEF.

The appointment of Kai Eide as Special Representative of the Secretary General (SRSG) led to greater international support for the lead role of the UN in Afghanistan. At the Paris donor conference in June 2008 it was agreed that the UN would play a key coordinating role in supporting the GOA in implementation of the Afghanistan National Development Strategy (ANDS). Although steps have been taken to adjust the struc- ture of UN to fulfill this role, so far the UN has not received sufficient additional resources or staff.

The majority of NGOs are of the opinion that the UN has a crucial coordinating role, provided it is principled in its approach and does not undertake increased 'integration' with the military, which will further compromise its independence and impartiality. In April 2008, 19 of the largest humanitarian NGOs in Afghanistan signed a letter to the UN calling for an independent UN OCHA (Office for the Coordination of Humanitarian Affairs) operation in Afghanistan. They cited concerns with deteriorating security and the humanitarian situation, lack of humanitarian information management, coordination and advocacy and the increasing integration of UNAMA and ISAF which they saw as compromising humanitarian space further. An independent OCHA would, they argued, improve the quality of the humanitarian space by promoting a clearer separation of humanitarian coordination from the new UNAMA-NATO integrated approach. ${ }^{19}$ After initial reluctance and much discussion it was decided that an OCHA office would be established, probably at the beginning of 2009. Although many NGOs have welcomed the latest decision, concerns remain about the capacity of the international community to address the current humanitarian crises over Winter, especially with, according to some predictions, a famine looming. ${ }^{20}$

\subsection{A Clearer Strategic Role for NATO forces}

ISAF's mandate should be defined more clearly and better linked to the civilian efforts of the GOA and the international community. The majority of the NGOs have argued for years that the PRTs should only be involved in security sector reform to create an enabling environment for development activities. On the other hand, given the reality on the ground that the PRTs are involved in reconstruction, development and governance, NGO argue that those activities should be based on best practices and models for ensuring conflict sensitive development planning (such as the widely used Do No Harm framework). Furthermore, they should be implemented in close coordination with the government. The different existing coordination mechanisms have so far not resulted in effective coordination mainly because of the lack of a common strategic approach. Currently, there are different national practices within ISAF and national caveats imposed by individual contributing countries take precedence over the need for a comprehensive and common ISAF approach. In order to ensure that co-ordination between UNAMA and ISAF extends beyond a limited collaboration between UNAMA and ISAF HQ, there is a need to enhance communication and co-ordination amongst all PRTs and ISAF HQ.

The majority of NGOs view the NATO mission as currently defined as misguided and counterproductive. The involvement of military forces in civilian tasks such as reconstruction and relief has been based on the presumption that such engagement

19 Letter to Mr. Bo Asplund, Deputy SRSG, United Nations Assistance Mission Afghanistan. "The Need for an independent OCHA in Afghanistan." April 4, 2008

20 Paul Smith, "Afghanistan - Preventing an Approaching Crisis." Royal United Services Institute Briefing Note, October 31, 2008. 
will provide troop protection and lead to increased security. Considering that Afghanistan is facing a steady deterioration in security with increases in both insurgent activity and crime, it might be time to revise this presumption. Moreover, recent research into community perceptions of PRTs and their work indicates that Afghans do not want military forces to carry out development and reconstruction projects because they feel there are "strings attached" to such projects and because the accountability of military forces is low: at the same time Afghans do see a role for the international military forces in security sector reform. ${ }^{21}$ Military forces should focus on security tasks and security sector reform, rather than continue their efforts in reconstruction and development where there are other actors with greater expertise.

\section{Conclusion}

Over the past years NATO has shown an increased interest in hearing NGO perspectives. NGO representatives are invited to meet with incoming members of the PRT, they are asked

21 Azarbaijani-Moghaddam and Wardak (2008). to speak at the NATO school and participate in international seminars and conferences. Although opportunities for public and constructive discussions are very much appreciated by the NGO sector, it has not necessarily led to noticeable changes on the ground.

Afghanistan represents an incredibly challenging scenario for NGOs. In the North NGOs often see themselves as partners in the peacebuilding strategy of the international mission while in the South NGOs are unwilling to be partners in the parallel warfighting strategy.

NGOs have had to reconcile their commitment to support needy Afghan communities with an operating environment created by international strategies they often directly oppose. No one suggests that NGOs have all the answers. However, for the best possible strategies for Afghan recovery to emerge, the views of the NGO sector and, those of the communities they work with, must be more given more than a token role in the policy dialogue with NATO. This dialogue needs to focus on other pressing issues beyond the militarization of aid, such as increasing insecurity, the predicted humanitarian crisis caused by continuing drought and food prices, and aid effectiveness for Afghanistan.

\title{
„Counterinsurgency“ - Neue Einsatzformen für die NATO?
}

\author{
Jochen Hippler*
}

\begin{abstract}
NATO has shifted its operational focus without a clear strategy. The Strategic Concept of 1999 is vague and leaves open a wide range of options. The US military has further developed earlier concepts of counterinsurgency. Boosted by what is seen as a successful application in Iraq, counterinsurgency is also being promoted in Afghanistan. However, there are major difficulties and deficits in applying counterinsurgency strategy, particularly in Afghanistan. Instead of adopting a counterinsurgency strategy for Afghanistan, NATO members should develop alternative strategies with a focus on political and economic reforms.
\end{abstract}

Keywords: NATO, military strategy, U.S., Afghanistan, Iraq; NATO, Militärstrategie, USA, Afghanistan, Irak

\section{Einleitung}

Afghanistan stellt eine besondere und qualitativ neue Herausforderung für die NATO dar. Die konventionelle und atomare Rüstung der NATO-Mitgliedsländer und ihre überwältigende militärische Überlegenheit sind offensichtlich keine Garantie dafür, die Aufgabe der Stabilisierung und des State-Building in Afghanistan erfolgreich zu bewältigen. Im Gegenteil: Seit 2004/2005 hat sich die Sicherheitslage dramatisch zugespitzt und die politische Situation zu einer kaum verhüllten Krise ent-

\footnotetext{
* PD Dr. Jochen Hippler ist wissenschaftlicher Mitarbeiter am Institut für Entwicklung und Frieden an der Universität Duisburg.
}

wickelt. Die Geheimverhandlungen mit den Taliban sind ein Ausdruck dieser Situation. Ohne die Erkenntnis, in Afghanistan in eine Sackgasse geraten zu sein, wäre die Unterstützung dieser Gespräche durch die NATO-Führungsmächte unvorstellbar. Die Erklärung für die dürftige Bilanz des NATO-Einsatzes in Afghanistan trotz der überwältigenden militärischen Überlegenheit des Bündnisses über die Aufständischen liegt in der Tatsache, dass der Afghanistankrieg keine konventionelle militärische Auseinandersetzung darstellt, sondern vor allem in Aufstandsbekämpfung besteht. Und diese Einsatzform - Counterinsurgen$c y$ - folgt ganz anderen Regeln als ein regulärer Krieg. Und auf sie sind die NATO und ihre Mitgliedsländer kaum vorbereitet, 